Acta vet. scand. 1984, 25, 425-435.

From the Department of Obstetrics and Gynaecology, Swedish University of Agricultural Sciences, Uppsala, Sweden.

\title{
SEMEN QUALITY AND FERTILITY AFTER HEAT STRESS IN BOARS
}

\author{
By \\ Lena Malmgren and Kjell Larsson
}

\begin{abstract}
MALMGREN, LENA and KJELL LARSSON: Semen quality and fertility after heat stress in boars. Acta vet. scand. 1984, 25, 425-435. - Sperm morphology and the fertilizing capacity of ejaculated spermatozoa were examined in 6 Swedish Landrace boars before and after heat stress. The boars were exposed to $35^{\circ} \mathrm{C}$ during $100 \mathrm{~h}$ in a climatic room. Fertility was measured by insemination of gilts before and at various times after heat stress. Each gilt $(n=44)$ was inseminated with a total of $5 \times 10^{9}$ spermatozoa diluted to $100 \mathrm{ml}$ with EDTA-glucose diluent and fertilization was assessed by examining recovered ova 2 days after insemination.

Changes in semen quality varied among the boars from a very weak response in 2 boars to pronounced semen alterations occurring 2-6 weeks after heat stress in the other boars. A close relationship was found between seminal changes and fertilization rates, all ejaculates which had high fertilization rates being of the same quality as the pre-exposure ejaculates. The ejaculates that had poor fertility were characterized by lowered sperm motility and increased numbers of spermatozoa with abnormal heads, proximal cytoplasmic droplets and nuclear pouch formations.
\end{abstract}

spermmorphology; fertilization; boar.

Lowered fertility and/or lowered total sperm counts and decreased ejaculate volumes have been found in boars during or shortly after the warm summer period in several countries (e.g. Okauchi \& Hirakata 1963, Thibault et al. 1966, Einarsson 1968, Stone 1977). In experimental studies various forms of heat stress have been used to induce similar changes. Lowered ejaculate volumes and total sperm counts have been found in some studies (Christenson et al. 1972, Stone 1982), but in other experiments (Wetteman et al. 1976, Cameron \& Blackshaw 1980, Einarsson \& Larsson 1982, Larsson \& Einarsson 1984) ejaculate volumes and total sperm counts remained unaffected. In most studies an in- 
crease of abnormal spermatozoa has been found (e.g. Wetteman et al. 1976, Einarsson \& Larsson 1982, Larsson \& Einarsson 1984). However, the results vary among experimental boars and also due to the different regimes for heat stress that have been used.

Lowered courting activity of the boars was found during heat stress (Winfield et al. 1981, Stone 1982) and apparent endocrine changes in plasma levels of cortisol and testosterone were found during and after heat stress (Einarsson \& Larsson 1980, Larsson et al. 1983). The fertility rate was decreased $2-6$ weeks after heat stress (Christenson et al. 1972, Wetteman et al. 1976, Stone 1982). In most of the aforementioner studies considerable variations among boars in their response to heat stress have been found. Furthermore the relationship between seminal changes and fertility have not been fully clarified. The purpose of the present study was to investigate the seminal changes in boars after exposure to heat stress and to relate these changes to the fertilizing capacity of the spermatozoa.

\section{MATERIALS AND METHODS}

Six mature (7-8 months) Swedish Landrace boars were used for the experiments. The boars originated from the same herd and were brought to the clinic at approximately 7 months of age. At the clinic they were kept in individual pens at barn temperature $\left(18^{\circ} \mathrm{C}\right)$ and were fed a standard ration of grain mixture and concentrates.

\section{Semen collection}

Semen was collected twice weekly during the whole experimental period, beginning $6-8$ weeks before heat stress and continuing until the semen quality was again normalized according to the standards of our laboratory (6-13 weeks after the heat stress). Semen collections were not performed while the boars were in the climatic room. The boars were allowed to mount the dummy sow in their own pens and the gloved hand technique was used for collection of semen. At collection the gel portion of the eajculate was filtered away through double gauze and the remaining part of the ejaculate was collected into a plastic bag in a preheated vacuum-flask. 


\section{Semen evaluation}

Ejaculate volumes were measured by means of $100 \mathrm{ml}$ graded cylinders. Sperm motility was estimated under a phase-contrast microscope at $37^{\circ} \mathrm{C}$ and at a maximum of $\times 400$ magnification. Semen morphology was assayed by phasecontrast microscopy of formol-saline fixed wet preparations and by light microscopy of William's stained dry smears. Sperm concentrations were measured by haemocytometric counting. At least 8 ejaculates with normal semen quality, according to the standards of our laboratory, were collected from each boar before exposure to heat stress. One of the boars showed increased numbers of spermatozoa with single-bent tails before exposure to heat stress. He was used in the experiments without fulfilling the demands on normalized sperm morphology before termination of semen collection.

\section{Climatic room}

The exposure to elevated temperature took place in a $3.5 \times$ $3.5 \mathrm{~m}$ temperature controlled room. The temperature in the room was kept at $35^{\circ} \mathrm{C}$ and the relative humidity at $40 \%$. The boars were kept in the climatic room for $100 \mathrm{~h}$.

\section{Fertility evaluation}

A total of 44 gilts (crossbred Swedish Landrace $\times$ Swedish Yorkshire, $7-8$ months of age) were used for the fertility tests. It was originally planned that gilts should be oestrus-synchronized with Oxolven $®$ (Mayer et al. 1977) for insemination with semen collected immediately before and 1, 3 and 6 weeks after heat stress. However, in too many cases ovarian cysts occurred (cf. Malmgren et al. 1983) and therefore only 10 gilts showing normal heat after synchronization were used and the remaining 34 were inseminated in spontaneous oestrus. For this reason the timing of inseminations relative to heat stress was less accurate than the original plan (see Table 2).

All gilts were checked for oestrus twice daily with the aid of a vasectomized boar and insemination was done once at $10-30 \mathrm{~h}$ after onset of standing heat. The inseminations were performed with a rubber spiral tip catheter according to Melrose \& O'Hagan (1961). The gilts were inseminated with $5 \times 10^{9}$ spermatozoa diluted to $100 \mathrm{ml}$ in EDTA-glucose diluent. All ejaculates used 
for insemination were examined as previously described and inseminations were performed within $6 \mathrm{~h}$ after semen collection. All gilts were slaughtered 2 days after insemination and the genital tract was removed immediately after stunning and bleeding. After a careful macroscopical examination the oviducts and upper parts of the uterine horns were flushed with saline for recovery of ova. The numbers of fresh corpora lutea (CL) in each ovary were recorded. The flushing solution was collected in Petri dishes which were then examined for presence of ova under a stereo-microscope at $\times 50$ magnification. Recovered ova were morphologically examined under an inverted phase-contrast microscope at $\times 400$ magnification. Ova with symmetrical cleavage (2- to 8-cell stages) were recorded as fertilized, whereas asymmetrically divided or undivided ova were classified as unfertilized. Ova with broken zona pellucida and empty zonae pellucidae were not included in the calculations of fertilization rate.

\section{Postmortem examination of the boars}

The boars were slaughtered when the semen qualitiy was again normal after heat stress. Immediately after stunning and bleeding the genital organs were removed and examined carefully. Specimens for histological examination were taken from two parts of each testicle. The specimens were fixed in Bouin's fixative and, after processing, slides were stained with haematoxylin-eosin and Van Gieson's stain.

\section{Statistical methods}

Standard statistical methods were used for evaluation of data. The relationship between seminal characteristics and fertilization rate was based only on the ejaculates that had been used for inseminations and, to illustrate this relationship, ejaculates that had a fertilization rate of more than $50 \%$ were compared with those that yielded less than $50 \%$ fertilization rate.

\section{RESULTS}

Seminal changes and sperm morphology are presented in Table 1. The values referred to as "before" represent 8 ejuculates from each boar. With the exception of the boar that had increased percentages of single-bent sperm tails, all boars had normal 
semen before exposure to heat stress. The high percentage of coiled and bent tails is due only to the aforementioned boar, which had an average of $26 \%$ single-bent sperm tails.

T a b l e 1. Semen characteristics of the boars before, $2-3,4-6$ and 7-9 weeks after heat stress. Overall means $\pm s$.

\begin{tabular}{|c|c|c|c|c|}
\hline & Before & Week 2-3 & Week 4-6 & Week 7-9* \\
\hline Motility (\%) & $68.0 \pm 4.7$ & $56.4 \pm 17.7$ & $53.8 \pm 17.6$ & $62.8 \pm 10.3$ \\
\hline $\begin{array}{l}\text { Ejaculate volume } \\
(\mathrm{ml})\end{array}$ & $141.6 \pm 46.4$ & $181.0 \pm 57.7$ & $155.8 \pm 62.5$ & $167.9 \pm 55.9$ \\
\hline $\begin{array}{l}\text { Total sperm } \\
\text { number } \times 10^{9}\end{array}$ & $37.1 \pm 14.4$ & $39.9 \pm 13.4$ & $36.8 \pm 20.8$ & $44.6 \pm 22.0$ \\
\hline \multicolumn{5}{|c|}{ \% sperm abnormalities: } \\
\hline Abnormal heads & $2.0 \pm 1.0$ & $11.8 \pm 20.2$ & $14.1 \pm 20.3$ & $1.9 \pm 2.0$ \\
\hline Prox.cytopl. droplets & $s \quad 0.4 \pm 0.6$ & $3.5 \pm 3.9$ & $7.4 \pm 8.5$ & $0.8 \pm 1.1$ \\
\hline Coiled and bent tails & $5.6 \pm 12.2$ & $11.0 \pm 18.9$ & $12.5 \pm 21.7$ & $9.6 \pm 18.7$ \\
\hline Abnormal acrosomes & $0.6 \pm 0.6$ & $2.1 \pm 3.1$ & $7.7 \pm 11.0$ & $0.7 \pm 0.9$ \\
\hline $\begin{array}{l}\text { Nuclear pouch } \\
\text { formations }\end{array}$ & 0 & $5.5 \pm 12.0$ & $3.6 \pm 14.3$ & 0 \\
\hline Abnormal midpieces & $2.2 \pm 3.5$ & $3.7 \pm 3.0$ & $5.0 \pm 4.5$ & $3.1 \pm 3.8$ \\
\hline No of boars & 6 & 6 & 6 & 4 \\
\hline No of ejaculates & 48 & 25 & 30 & 25 \\
\hline
\end{tabular}

* The 4 boars with latest normalization of semen.

There were no consistent changes in ejaculate volumes and total sperm counts after heat stress, while there was an apparent decline in sperm motility during weeks $2-6$ after heat stress. In 3 boars increased numbers of sperm abnormalities were found during weeks 2-6 after heat stress and in a fourth boar increased numbers of abnormal spermatozoa were found during weeks 4 7 after heat stress. The remaining 2 boars only had a minor increase in abnormal sperm heads (up to $11 \%$ ) during a short period (week 3 ) after heat stress. The data summarized in Table 1 are overall means for all boars and the reason for the relatively slight increases seen in the table is the different patterns among the boars. The high percentage of coiled and bent tails is entirely related to the boar that had this abnormality already before heat stress, and the data for this boar are summarized in Table 1a.

The lowest fertilization rate was obtained with semen collected 2 -3 weeks after termination of heat stress (Table 2). An im- 
T a b l e 1 a. Semen characteristics of the boar with increased incidences of bent and coiled tails.

\begin{tabular}{lrrrrr}
\hline & Before & Week 2-3 & Week 4-6 & Week 7-9 & Week 10-12 \\
\hline Motility (\%) & $65.0 \pm 7.1$ & $13.3 \pm 7.6$ & $8.3 \pm 5.8$ & $48.0 \pm 18.0$ & $11.9 \pm 17.7$ \\
$\begin{array}{l}\text { Ejaculate volume (ml) } \\
\text { Total sperm }\end{array}$ & $131.9 \pm 59.3$ & $180.0 \pm 30.4$ & $231.7 \pm 43.1$ & $210.0 \pm 51.3$ & $207.1 \pm 43.0$ \\
number $\times 10^{9}$ & & & & & \\
& $42.5 \pm 21.3$ & $56.0 \pm 11.0$ & $82.3 \pm 21.0$ & $55.6 \pm 17.4$ & $62.3 \pm 27.7$ \\
$\%$ Sperm abnormalities: $:$ & & & & & \\
Abnormal heads & $1.4 \pm 0.6$ & $6.0 \pm 5.7$ & $9.1 \pm 4.9$ & $1.6 \pm 1.4$ & $5.3 \pm 4,3$ \\
Prox. cytopl. droplets & $0.4 . \pm 0.6$ & $4.3 \pm 2.4$ & $7.7 \pm 6.5$ & $0.6 \pm 0.6$ & $1.0 \pm 1.2$ \\
Coiled and bent tails & $26.3 \pm 19.5$ & $53.2 \pm 20.4$ & $70.3 \pm 13.1$ & $35.8 \pm 24.1$ & $66.2 \pm 13.3$ \\
Abnormal acrosomes & $0.5 \pm 0.5$ & $0.7 \pm 0.8$ & $2.5 \pm 1.8$ & $0.3 \pm 0.4$ & $2.6 \pm 5.8$ \\
$\begin{array}{l}\text { Nuclear pouch } \\
\text { formations }\end{array}$ & 0 & & & & \\
Abnormal midpieces & $7.8 \pm 5.2$ & $4.3 \pm 1.6$ & $11.7 \pm 6.6$ & $6.4 \pm 4.4$ & $6.1 \pm 6.3$ \\
\hline
\end{tabular}

provement was seen 5-6 weeks after heat stress and for the late recovering boars the fertilization rate was very high for semen collected 7-10 weeks after heat stress. The data presented in Table 2 include all gilts inseminated during these periods and semen from all boars was used. Four of the inseminated gilts are not presented in the table because 1 was inseminated in week 1 and the other 3 in weeks $11-13$; data from these gilts are included only in Table 3.

T a b l e 2. No. of inseminated gilts, no. of recovered and fertilized ova before and after heat stress of the boars.

\begin{tabular}{lrcccc}
\hline & $\begin{array}{c}\text { No. of gilts } \\
\text { inseminated }\end{array}$ & gilts/boar & No. of c.l. $\begin{array}{c}\text { No. of ova } \\
\text { recovered }\end{array}$ & $\begin{array}{c}\% \text { fertilized } \\
\text { ova }\end{array}$ \\
\hline Before heat stress & 14 & $1-3$ & 154 & 115 & 78 a,c \\
2-3 weeks after & 12 & $1-3$ & 144 & 92 & 63 b \\
$5-6$ weeks after & 6 & $1-3$ & 73 & 51 & 67 a,b \\
$7-10$ weeks after & 8 & $1-3$ & 85 & 53 & 89 c \\
\hline
\end{tabular}

Fertilization rates with different superscripts differ significantly $(P<0.05)$.

The greatest effect on fertility was seen when ejaculates with low sperm motility and high numbers of abnormal spermatozoa were used. Most ejaculates collected before heat stress had a more than $50 \%$ fertilization rate and, as seen in Table 3 , the ejaculates with a more than $50 \%$ fertilization rate collected after heat stress 
had a semen quality close to that found before heat stress. The ejaculates that had low fertilization rates were characterized by lowered sperm motility and increased numbers of sperm abnormalities.

T a b le 3. The relationship between fertilization rates and ejaculate characteristics (mean $\pm s$ ).

\begin{tabular}{lccc}
\hline$\%$ & $\begin{array}{c}50 \% \text { ferti- } \\
\text { lized ova }\end{array}$ & $\begin{array}{c}>50 \% \text { ferti- } \\
\text { lized ova }\end{array}$ & $\mathrm{r}$ \\
\hline Motility & $44.2 \pm 28.1$ & $63.4 \pm 10.5$ & $0.53^{\star \star \star}$ \\
Abnormal heads & $18.8 \pm 29.1$ & $4.0 \pm 6.5$ & $-0.47^{\star \star}$ \\
Prox. cytopl. droplets & $5.4 \pm 6.5$ & $1.6 \pm 2.9$ & $-0.43^{\star \star}$ \\
Coiled and bent tails & $22.2 \pm 28.1$ & $7.1 \pm 16.2$ & $-0.41^{\star \star}$ \\
Abnormal acrosomes & $4.5 \pm 4.3$ & $1.7 \pm 2.2$ & $-0.24 \mathrm{n} \mathrm{s}$ \\
Nuclear pouch formations & $5.3 \pm 13.5$ & $0.7 \pm 3.2$ & $-0.33^{\star}$ \\
Abnormal midpieces & $5.2 \pm 4.7$ & $2.1 \pm 2.7$ & $-0.25 \mathrm{n} \mathrm{s}$ \\
No gilts & 13 & 31 & \\
No of cl & 159 & 354 & \\
No of recovered ova & 119 & 237 & \\
No of fertilized ova & 17 & 220 & \\
$\bar{x}$ fertilization \% & $14.0(0-50)$ & $93.0(63-100)$ & \\
\hline
\end{tabular}

$\mathrm{P}<0.05^{\star}, \mathrm{P}<0.01^{\star \star}, \mathrm{P}<0.001^{\star \star *}, \mathrm{P}>0.05 \mathrm{n} \mathrm{s}$.

Significant correlations were found between fertilization rate and sperm cell motility, \% abnormal sperm heads, \% spermatozoa with proximal cytoplasmic droplets, $\%$ coiled and bent tails and $\%$ spermatozoa with nuclear pouch formations (Table 3 ). The correlations were calculated for each semen characteristic without correcting for any possible combined effects.

Most of the fertilized ova had 10 or more spermatozoa attached to the zona pellucida, whereas very few of the unfertilized ova had any spermatozoa in the zona pellucida (Table 4). Furthermore, when low quality semen was inseminated, few ova had any spermatozoa attached to the zona pellucida (Table 5).

T a b le 4. The relationship between fertilization and spermatozoal attachement to the zona pellucida.

\begin{tabular}{ccc}
\hline $\begin{array}{c}\text { Number of spermatozoa attached } \\
\text { to the zona pellucida }\end{array}$ & \multicolumn{2}{c}{ Number of ova } \\
\cline { 2 - 3 } & fertilized & unfertilized \\
\hline $1-10$ & 17 & 96 \\
$>10$ & 72 & 13 \\
\hline
\end{tabular}


Table 5. The relationship between the numbers of spermatozoa attached to zona pellucida and ejaculate characteristics (mean $\pm s$ ).

\begin{tabular}{lrrr}
\hline & Number of spermatozoa attached to zona pellucida \\
$\%$ & 0 & $1-10$ & $>10$ \\
\hline Motility & $37.2 \pm 30.2$ & $61.0 \pm 11.9$ & $66.0 \pm 4.6$ \\
Abnormal heads & $14.9 \pm 27.0$ & $3.0 \pm 2.9$ & $2.6 \pm 2.3$ \\
Prox. cytopl. droplets & $5.7 \pm 6.2$ & $1.9 \pm 3.6$ & $1.3 \pm 2.3$ \\
Coiled and bent tails & $28.9 \pm 26.2$ & $10.4 \pm 17.9$ & $1.6 \pm 3.3$ \\
Abnormal acrosomes & $4.9 \pm 6.4$ & $2.3 \pm 7.0$ & $1.3 \pm 1.3$ \\
Nuclear pouch formations & $4.5 \pm 11.3$ & $1.0 \pm 3.3$ & $0 \pm 0.1$ \\
Abnormal midpieces & $5.6 \pm 3.9$ & $3.4 \pm 3.1$ & $2.5 \pm 2.7$ \\
\hline
\end{tabular}

None of the boars had any macroscopical alteration in the genital organs. Histological examination of the testicles revealed that most tubuli seminiferi were normal. In all of the boars a few tubuli with signs of degeneration were seen.

\section{DISCUSSION}

The seminal changes found after heat stress are in close agreement with those found in previous experiments in our laboratory, utilizing the same climatic room and similar animals (Einarsson \& Larsson 1980, Larsson \& Einarsson 1984). However, in the present study the variations in response among the experimental boars were more apparent. The variations are most likely explained by differences among the boars in heat resistance or differences in the ability to adapt to the new environment.

Apart from the previously described seminal alterations, i.e. lowered sperm motility and increased numbers of spermatozoa with proximal cytoplasmic droplets and abnormal sperm heads, also increased numbers of spermatozoa with nuclear pouch formations were found during the period after heat stress. The abnormality was not found in a single ejaculate before heat stress. The abnormality was not found in a single ejaculate before heat stress nor in the ejaculates collected after normalization of other sperm characteristics. This observation is in agreement with the results of Bane \& Nicander (1965), who found the pouch formations to be related to a disturbance in spermiogenesis.

In the present study fertility was only estimated as fertilization rate shortly after insemination. Thus further negative effects on embryonic survival, were not accounted for. The present results clearly indicate a relationship between seminal changes 
and the fertilizing ability of the spermatozoa. The present results are in agreement with the results presented by Wetterman et al. (1976, 1977).

The time lapse from heat stress to the occurrence of lowered sperm motility and increase of abnormal spermatozoa in the ejaculates indicates that spermiogenesis, but not earlier stages of the spermatogenesis, was negatively affected. As indicated by the increased of spermatozoa with proximal cytoplasmic droplets, also epididymal sperm maturation might have been influenced. Although the percentage of abnormal spermatozoa was very high in single ejaculates, the mean numbers in the ejaculates that had poor fertilization rates are surprisingly low. However, the fact that the unfertilized ova rarely had any spermatozoa attached to the zona pellucida indicates that the fertilizing ability and/or the uterine-oviductal transport was affected also in morphologically normal spermatozoa.

The results of this study indicate that it is possible to use semen evaluation as an indicator of fertility in a boar that has been exposed to heat stress or presumably to any other kind of environmental disturbance.

\section{ACKNOWLEDGEMENTS}

This investigation was supported by grants from the Swedish Council for Forestry and Agricultural Research. The authors are indebted to Karin Selin-Wretling and Kerstin Lindblad for examinations of sperm morphology and to Marie Wallbring, Eva Hedberg and Helene Gille for expert care of the experimental animals. The Department of Animal Hygiene provided the climatic room and the help given by $\mathrm{Dr}$ Juhani Hakkarainen was of great value.

\section{REFERENCES}

Bane, A. \& L. Nicander: Pouch formations by invaginations of the nuclear envelope of bovine and porcine sperm as a sign of disturbed spermiogenesis. Nord. Vet.-Med. 1965, 17, 628-632.

Cameron, R. D. A. \& A. W. Blackshaw: The effect of elevated ambient temperature on spermatogenesis in the boar. J. Reprod. Fert. $1980,59,173-179$.

Christenson, R. K., H. S. Teague, A. P. Grifo Jr \& W. L. Roller: The effect of high environmental temperature on the boar. Ohio Swine Research and Information Report 1972, p. 19-23.

Einarsson, S.: Factors affecting fertility in artificial insemination of swine. Nord. Vet.-Med. 1968, 20, 622-629. 
Einarsson, S. \& K. Larsson: Endocrine effects of elevated ambient temperature in boars. Proc. IXth Int. Congr. Anim. Reprod. \& AI., Madrid, 1980, IV, 736-740.

Einarsson, $S . \& K$. Larsson: Exposure of boars to elevated ambient temperature: Morphological studies of the ejaculated semen. Proc. IPVS. Congr., Mexico City 1982, p. 215.

Larsson, $K$. \& S. Einarsson: Seminal changes in boars after heat stress. Acta vet. scand. $1984,25,57-66$.

Larsson, K., S. Einarsson, K. Lundström \& J. Hakkarainen: Endocrine effects of heat stress in boars Acta vet. scand. 1983, 24, 305314.

Malmgren, L., K. Karlberg \& L. Göransson: Synchronization of oestrous in gilts with a progestin [Oxolven (Sa 45.249)]. Nord. Vet.-Med. $1983,35,360-363$.

Mayer, P. \& E. Schütze: A new progestin (Sa 45.249) for cycle control in pigs. Communications I-IV, Theriogenology 1977, 8, 357$366,389-402$.

Okauchi, K. \& K. Hirakata: Studies on the characters of boar semen. I. Effects of environmental temperature. Bull. Fac. Agric., Univ. Miyazaki, 7:17 (In ABA 1963, 31, 388).

Stone, B. A.: Between and within herd variations in conception rates in pig herds in the lower North of South Australia. Agric. Rec. S. Aust. 1977, 4, 22-25.

Stone, B. A.: Heat induced infertility of boars: the inter-relationship between depressed sperm output and fertility and an estimation of the critical temperature above which sperm output is impaired. Anim. Reprod. Sci. 1981/82, 4, 283-299.

Thibault, C., M. Courot, L. Martinet, P. Mauleon, F. Du Mesnil du Buisson, R. Ortavant, J. Pelletier \& J. P. Signoret: Regulation of breeding season and oestrous cycles by light and external stimuli in some mammals. In "Environmental Influences on Reproductive Processes". eds. W. Hansel \& R. H. Dutt. J. Anim. Sci. (suppl.) 1966, 25, 119-142.

Wetteman,R. P., M.E. Wells, I. T. Omtvedt, C. E. Pope \& E. J. Turman: Influence of elevated ambient temperature on reproductive performance of boars. J. Anim. Sci. 1976, 42, 664-669.

Wetteman, R. P., M. E. Wells, L. W. Brock, R. K. Johnsson, R. Harp \& $R$. Vencl: Recovery of normal semen quality after heat stress of boars. Anim. Sci. Research Report. Oklahoma 1977.

Winfield, C. G., P. H. Hemsworth, D. B. Galloway \& A. W. Makin: Sexual behaviour and semen characteristics of boars: effects of high temperature. Aust. J. Exp. Agric. Anim. Husb. 1981, 21, $39-45$.

\section{SAMMANFATTNING}

Inverkan av förhöjd omgivningstemperatur på spermiekvalite och fertilitet hos galt.

Morfolog1 och befruktningsförmåga hos ejakulerade spermier undersöktes hos 6 stycken Svenska Lantrasgaltar, före och efter värme- 
stress. Galtarna vistades $\mathrm{i}$ en klimatkammare där de exponerades för $35^{\circ} \mathrm{C}$ i 100 tim. Fertiliteten bedömdes genom att gyltor $(n=44)$ inseminerades med sperma som samlades före, och vid olika tidpunkter efter värmestressen.

Till varje insemination användes $5 \times 10^{9}$ spermier utspädda till $100 \mathrm{ml}$ med EDTA-glukos lösning. Gyltorna slaktades 2 dygn efter insemination och befruktningsförmågan bedömdes genom att antal befruktade respektive obefruktade ägg räknades.

Förändringarna i spermiekvaliten varierade hos galtarna, från ringa förändringar hos 2 av galtarna till uttalade spermiemorfologiska förändringar som varade $\mathrm{i} 2-6$ veckor efter värmestressen hos de övriga 4 galtarna. Ett nära samband påvisades mellan de spermiemorfologiska förändringarna och befruktningsförmågan, vilket innebar att ejakulat som gav en hög befruktningsfrekvens också uppvisade en spermiekvalite som ej avvek från de ejakulat som samlats före värmestressen. Ejakulat med låg befruktningsförmåga karakteriserades av sänkt spermiemotilitet och ökat antal spermier med patologiska huvudformer, proximala droppar och kärnsäckar.

(Received June 12, 1984).

Reprints may be requested from: Lena Malmgren, the Department of Obstetrics and Gynaecology, Swedish University of Agricultural Sciences, S-750 07 Uppsala, Sweden. 